\title{
Article
}

\section{Commemorating tragic heroes: statuary of soccer players who died mid-career}

Stride, Christopher, Thomas, Ffion and Chamorro, Ana Maria Available at http://clok.uclan.ac.uk/18210/

Stride, Christopher, Thomas, Ffion and Chamorro, Ana Maria (2019) Commemorating tragic heroes: statuary of soccer players who died midcareer. Soccer and Society, 20 (3). pp. 431-453. ISSN 1466-0970

It is advisable to refer to the publisher's version if you intend to cite from the work. http://dx.doi.org/10.1080/14660970.2017.1331162

For more information about UCLan's research in this area go to http://www.uclan.ac.uk/researchgroups/ and search for < name of research Group>.

For information about Research generally at UCLan please go to http://www.uclan.ac.uk/research/

All outputs in CLoK are protected by Intellectual Property Rights law, including Copyright law. Copyright, IPR and Moral Rights for the works on this site are retained by the individual authors and/or other copyright owners. Terms and conditions for use of this material are defined in the policies page.

\section{CLoK}

Central Lancashire online Knowledge www.clok.uclan.ac.uk

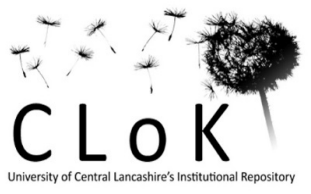


Version: Accepted Version

\section{Article:}

Stride, C.B. orcid.org/0000-0001-9960-2869, Thomas, F.E. and Chamorro, A.M. (2017) Commemorating tragic heroes: statuary of soccer players who died mid-career. Soccer and Society. ISSN 1466-0970

https://doi.org/10.1080/14660970.2017.1331162 


\section{Commemorating Tragic Heroes: Statuary of Soccer Players Who Died Mid-}

\section{Career}

Memorialization in sport is uniquely organized into ritual acts of commemoration, creating representations that, according to Armstrong, "enact and [give] social substance to the discourse of collective memory."1 The embodiment of such representations as material objects provides what Mol terms as "a frame of reference where they can appear in a more orderly, more consistent, and more timeless way.",2 Within the realm of association football (soccer), prominent examples of such 'objectification' are the figurative statues depicting soccer players, erected in a variety of locations that reflect the sport's global popularity. ${ }^{3}$ As of April 2017, 286 statues or statue groups collectively depicting over 350 distinct players, and a further 177 anonymous figures, stand at stadiums or civic sites around the world. ${ }^{4}$

Monuments such as statues speak as much of the values, attitudes and beliefs of those who produce them, the types of archival materials that survive, and contemporary memory politics, as they do of the subjects they depict. ${ }^{5}$ Andreas Huyssen attributes this to the "...fissure that opens up between experiencing an event and remembering it in representation... Rather than lamenting or ignoring it, this split should be understood as a powerful stimulant for cultural and artistic creativity."6

Accordingly, these bronze ballplayers can tell us how soccer clubs and their fans seek to construct and project cultural memories from a combination of their social mores, motivations and their perception of the hero depicted. Further, through their global presence, they offer a lens through which to examine the similarities, differences and 
temporal changes in soccer cultures across national boundaries. This article seeks to engage with the possibilities offered by a subgroup of soccer statues - those that honour professional footballers who died suddenly during their playing careers - to examine, compare and contrast how sporting tragedies are interpreted, commemorated and reimagined, and in doing so, simultaneously address gaps within the small but expanding scholarly literature on figurative sporting sculpture. ${ }^{7}$ The authors have identified 20 such full body figurative memorials, in situ as of $1^{\text {st }}$ April 2017.

We begin with an overview of the wider soccer statuary and its motivations. We posit that statues of recently deceased active players stand apart in their motivation and meaning. Our study then focuses on a detailed examination and comparison of two such memorials, which honour players of similar backgrounds, who had reached similar career stages and levels of achievement upon their deaths, but who came from distinct soccer cultures. We demonstrate how the location and design of these statues, and the commemorative events and practices associated with them, speak of how different societies organise, interpret and respond to the world. ${ }^{8}$ These monuments, erected for the purposes of commemoration, interact with place and presentation in the formation of collective memory and in taking on other meanings.

\section{Soccer Player Statues}

Almost $95 \%$ of soccer player statues have been erected within the past 20 years. ${ }^{9}$ This supports Eelco Runia's claim that the desire to commemorate in the wider social context is "one of the prime historical phenomena of our time." ${ }^{10}$ Erika Doss, in her critique of the United States' boom in commemoration, both temporary and permanent, argues that it reflects a shift towards public feeling as a source of 
knowledge. ${ }^{11}$ This interest in experiencing history, not just seeing it, is facilitated by contemporary artists, architects and memorial makers. ${ }^{12}$ Yet whilst the burgeoning soccer statuary dovetails with the wider increase in monumental commemoration, its figurative form, typically raised on a plinth, bucks the trend towards abstract designs that prioritise creating spaces for public interaction rather than elevating heroes. Soccer heroes are typically rendered in a deeply traditional figurative portraiture, resembling both the Olympian statuary of ancient Greece, and the kings, queens, and generals commemorated in the first wave of 'statue fever' that gripped both Europe and the USA in the late $19^{\text {th }}$ century. ${ }^{13}$

According to Taylor, the links to the past forged by commemorative gestures such as statues help to "order and give meaning to the present" in soccer as much as in everyday life. ${ }^{14}$ However, statues represent a significant expense for the clubs, fans and civic bodies who erect them, and to consider them purely as reflections of their sponsors' altruism would overlook the benefits that public art and built heritage can offer to host organisations and places, as well as failing to explain their recent growth. ${ }^{15}$ A more likely explanation for much of the rapid accumulation in soccer player statues over the past two decades is clubs' adoption of a marketing strategy based upon evoking nostalgia. Experiencing nostalgic sentiments, i.e. favourable thoughts about, or even a preference for past experiences, places, people or objects, has been shown to stimulate consumers' likelihood to purchase, and more specifically within the sporting context, increase fan attachment and stimulate sports tourism. ${ }^{16}$

A second motivating force behind the prevalence of soccer statues is the desire by clubs, fans and communities to proclaim a successful, distinctive and, above all, 
authentic identity, often within refurbished stadium and civic landscapes that are increasingly commercialised, homogenous, or, in the words of Bale, 'placeless' ${ }^{17}$ As Dixon notes, 'football fans inhabit a culture where authenticity is constantly scrutinised by themselves and others'; Bale believes that such authenticity is threatened by 'the development of the sanitised, safe, concrete but placeless stadium which will possess fewer landscape elements and simply less scenery for the spectator to absorb and enjoy'. ${ }^{18}$ For a soccer club, projecting their authenticity is often contiguous with evoking nostalgia since, as fans age, their construction of what is authentic is inevitably tainted by nostalgic reminisce. The effectiveness of this nostalgia-authenticity nexus is in part due to the hyper-commodification of top division soccer that has occurred over the past two decades. ${ }^{19}$ Commercialisation represents an unwelcome turn for many long-standing supporters, particularly those that Giulianotti classifies as 'hot-traditional', a demographic whose strong allegiance to their club is neither founded upon nor dependent upon playing success, and is partially defined by a strong topophilic attachment to their club's stadium. ${ }^{20}$ Statues, as with other leveraging of a club's heritage, such as the offer of retrospective kit designs, murals, club museums, and the naming of stands after past players offer both a panacea - by encouraging and enabling fans to identify their club as the traditional historically-rooted entity they would wish to support - and a PR distraction from the more commercial aspects of the modern game, such as wage inflation and rising ticket prices. Yet, somewhat ironically, statues also appeal to the much-pursued revenue streams represented by as yet uncommitted fans or sports tourists, who are attracted by 'tradition'. 
Similarly, a civic statue of a located local hero provides identity to otherwise indistinguishable, increasingly placeless urban landscapes, especially in settlements where formerly dominant industries have declined, stripping the town of its raison d'etre, or where commercial redevelopment has erased long-standing local landmarks. This is evident in the civic locations that boast soccer statues. Soccer player monuments are rarely found in the centres of capital cities - where nationallyrenowned royal, military or religious figures are still competing for the honour of being cast in bronze, and national acclaim is a prerequisite for selection - but they occur more frequently in smaller towns or suburban settings, where the local context resonates more strongly.

Though not the only sport to have statues, soccer's inventory dominates globally, both in numeric terms, and in the breadth of its distribution across six continents and 66 countries, reflecting the sport's worldwide appeal. For instance, the second largest sport statuary we have identified, that of over 200 baseball players, is concentrated almost entirely within the United States, with just a handful of examples in Mexico, the Caribbean islands and Japan. ${ }^{21}$ Soccer players (and those in other team sports) hold an advantage over athletes from individual sports in their likelihood of being honoured by a statue, through being connected to a sports organisation or franchise. Professional sports teams may not only be motivated to erect a statue by the reasons outlined above, but their committed fans provide a pool of potential organisers and funders, and their stadium provides a natural site for a statue. As such, statues of competitors in individual sports are both rarer and, where they do occur, largely placed in civic sites. ${ }^{22}$ This predominance of professional team sport athletes in the global sport statuary, combined with the relative lack of funding and spectator support 
for women's professional team sports, is one reason for the lack of female sport statue subjects. Female athletes have occasionally been depicted, most frequently successful Olympians. ${ }^{23}$ However, though a small number of statues of anonymous female soccer players and fans are in situ, a female soccer professional is yet to be sculpted. ${ }^{24}$

Given that an individual's strongest memories and hence the sources of their nostalgic feelings are connected to their adolescence and young adulthood, clubs will wish to remind fans of their teenage heroes. ${ }^{25}$ It is therefore unsurprising that over half of soccer statue subjects were alive when their portrayal was unveiled. ${ }^{26}$ This pattern is not purely a product of Northern European soccer cultures. Clubs, fans and civic authorities in the traditional soccer nations of Latin Europe and Latin America, in soccer's new horizons of East Asia, and in sports such as baseball and basketball, celebrate the living at least as often as commemorating the deceased. ${ }^{27}$ Within the inventory of soccer statues only those in Eastern Europe, where being honoured with a statue whilst alive would be considered a harbinger of doom, eschew this trend. ${ }^{28}$

Examples of a soccer player being honoured by a statue during his career are, however, rare: in almost all cases the player concerned was a world class performer approaching retirement. ${ }^{29}$ Such scarcity supports our cited motivation for many soccer statues - it is unlikely that choosing a still-active player as a statue subject (or indeed a player who passed away decades before contemporary fans were born) would generate significant levels of nostalgia. Additionally, the career achievements and contribution of a player who is still playing cannot be assessed and compared against contemporaries and predecessors in the same way as they can for a player who has retired. This lack of contemporary subjects also supports the hypothesis that, where a 
deceased subject of playing age is portrayed, their statue has been motivated primarily by the collective grief of a life and career cut unexpectedly short as opposed to their career achievements to that point, and therefore represents a very different type of monument.

\section{Memorialising the sudden death of a soccer player}

Despite their relative rarity, statues of recently deceased active players are still deeply rooted within the publicly-sited subject-specific soccer statuary. The first such monument, that commemorating FC Sinćeliću player Ljubomir Jakovljevic, dates back to 1927. It was erected in the town of Nis after he had drowned whilst rescuing a child from a swollen river the previous year. Figure 1 below compares the increase in statues of recently deceased active players to the corresponding accumulation in statues of living or retired players. The pattern of recent rapid expansion is consistent across these subgroups, albeit with the former category accumulating in a less prolific manner, given the thankful rarity of such deaths.

Figure 1: Cumulative numbers of subject-specific statues of soccer players by year of unveiling, split by whether subject was alive or dead, active or retired, and contemporaneity of death to unveiling

$<$ Figure 1 here>

Russell comments that, "commemoration and memorialization have become central taken-for-granted features of English (and indeed, British) soccer culture within the last two decades. ${ }^{30}$ Speaking in a broader societal context, archaeologists Claire Corkhill and Ray Moore echo Doss in defining this trend as 'memorial mania', and 
relate it to an increase in all types of public displays of mourning surrounding deaths that occur suddenly, unexpectedly or violently. ${ }^{31}$ Russell, Corkhill and Moore were all writing in the context of British custom: care should be taken not to automatically extrapolate the changes seen in the mourning culture of English soccer, and the timing of them, to a worldwide sample. Indeed, when framing the overt symbolic and ritualistic aspects of post-Hillsborough mourning in the context of Liverpool's status as a strongly Irish-Catholic-influenced city in a largely Protestant country, Guilianotti notes the influence of "natural Celtic expressiveness" and their deep tradition of expressive mourning rituals. ${ }^{32}$ However, regardless of global and faith-based heterogeneity in the style and tone of (non-sport-related) national mourning culture, the recency of all but one of this sub-genre of soccer statues (Figure 1) and their relatively even spread across a wide range of nations (Figure 2) suggests that memorial mania in the specific form of soccer statues can be extended to many national soccer cultures.

Figure 2: Numbers of statues of soccer players commemorated within 3 years of death who were active players at the time of death, split by nation

$<$ Figure 2 here >

Previous studies examining the monuments dedicated specifically to deceased sportsmen and women have focused variously on graveyards and cemetery locations, the shrines of 'danger sports' such as motor-racing, and on non-material artefacts such as the minute's silence or applause. ${ }^{33}$ Within the narrower remit of memorialising dead soccer players, McGuiness, Russell and Herzog have each examined players and managers who died later in life. ${ }^{34}$ However, these articles and other such scholarly 
inquiry have tended to be based around single or small sample case studies. The presentation of a wider sample, one that might enable contextual and cross-cultural comparison, is restricted to two compendiums of German examples, respectively compiled by Wangen, and by Cardorff and Böttger. ${ }^{35}$

Furthermore, the passing of an active competitor in 'danger' sports such as motorracing or mountaineering, where the threat to life is inherent in the activity and fatal accidents are more frequent, or the death of aged, long-retired stalwart footballer, are neither unexpected nor particularly rare or inexplicable events, hence they are likely to have a different impact to the sudden loss of a soccer player during their career. Adding to the shock caused by the death of an active soccer star is the degree of immersion that soccer fans experience within the lives of their teams and their players. The expansion of media formats and platforms and commodification of its personalities has increased the regularity and depth of soccer fan engagement. As several commentators have noted, $21^{\text {st }}$ century professional soccer resembles a 24 hours-a-day rolling soap opera constructed around a weekly sporting contest. ${ }^{36}$ For many supporters, soccer acts as a form of escapism from the mundane realities and trials of everyday life. Soccer players are real-time superheroes, capable of athletic feats beyond the rest of us, unbound by many of the same physical constraints. Watching them can make us feel immune to the real world. Sport becomes our great escape from life's darker mortality, an alternative playground where the narrative is of battles and victories, but from which everyone walks away to fight another day. ${ }^{37}$ As such, the unexpected death of a soccer player represents an intrusion of very real loss into this parallel universe of immortals, especially during the season when their sudden absence from the weekly team sheet would be a stark reminder. 
Before examining specific examples of the genre, we consider what makes the use of a statue to memorialise the sudden death of a sportsman during his career a distinctive scenario from commemoration during his lifetime or following death after retirement. Specifically, we investigate impacts upon the 'sites of meaning' of visual material described by Huggins and O’Mahony: the 'site of production' (the instigation, funding and production process), the 'visual image or object' (i.e. the design of the statue), and 'the sites of reception and seeing' (which encompasses both the macrolocation factors of geography and type, and the presentation of the statue e.g. the interpretative material provided). ${ }^{38}$

As Mitchell notes, 'Memory is bound up with power, and both memory, and its corollary, forgetting, are hegemonically produced and maintained, never seamlessly or completely, but formidably and powerfully nonetheless. ${ }^{, 39}$ Thus we need to think in terms of distinctiveness and differences with respect to control of the memorialisation process. In all sites of meaning, the wishes of the subject's family will be a primary consideration given the loss they have experienced. Beyond their mandate there will exist a relative power vacuum with the other stakeholders primarily clubs and fans, but also the sculptor - wishing to be seen to be sensitive to the family and public feeling, and to make outwardly harmonious consensus decisions.

Stories of remembrance require a place where they can be told. Through its macro and micro level characteristics, the location chosen for a statue feeds into the meanings it projects and the collective memories it inspires, and in turn the location has its own 
meaning adapted. This process operates through the way in which location determines who visits a statue, when they visit and how often they visit. The majority of club or fan funded subject-specific statues of soccer players are located at the stadium where the subject plied his trade. A stadium-sited statue of a deceased player permanently links the subject to the host club (even if their career history might have encompassed many other clubs and stadia, some of which may have featured more prominently). It reinforces the parallels often drawn between soccer and organised religion by creating a shrine or alternative grave located within a cathedral of the subject's sport. ${ }^{40}$ If the statue's micro-level location is on a public concourse (as it usually is), a stadium location will guarantee repeated visits from devotees of the subject, though these visits will rarely be made primarily to visit the monument. Over time, the statue will become part of the stadium as opposed to a standalone object, with the stadium reciprocally becoming part of any associated commemorative rituals.

Likewise, a local government commission would most often reside in a public square or park, reflecting the use of public money and wider public recognition of the subject. Here the statue enables commemoration to be shared with a non-soccersupporting population. For those who did not witness the statue subject in action, the statue may stir a less powerful sense of loss than it does for fans of the club; their lack of competing first-hand recollections, however, mean the statue image may have proportionally greater impact in creating a memory of the player.

The location of a statue commemorating a recently deceased player is less rigidly determined than that of a more typical soccer player statue, due to the greater separation of the primary funder (typically club or fans) from the primary mandate. 
Where the statue subject is recently deceased, a need to show respect to the bereaved family makes their mandate essential when choosing the location, albeit allied with consensus amongst fans, club officials, and in some instances the wider local population, who may regard the subject as their city's hero.

Both stadium and civic locations are viable sites. If the player's death is linked with the stadium, in that it was caused by an injury or medical condition that was sustained or became apparent during a match, or even occurred there, the stadium is an extremely sensitive site for a statue - one that might possible considered too morbid by reminding fans of their witnessing the player's death as much as celebrating his life. There also exists the additional possibility of a grave statue, depending on cultural tradition. As Huggins notes, memorials set within a graveyard "invite a markedly different response to that of public monuments, and evoke different rituals of remembering"; furthermore, graveyards may be segregated into areas according to social class or achievement. ${ }^{41}$ Even beyond any national custom, the likelihood of a statue being erected graveside is enhanced where the subject died suddenly at a young age. An early death is more likely to be a life mourned than celebrated; a sombre place of mourning is a more appropriate site. Additionally, given the greater influence of family, close relatives and religious beliefs at a time of heightened emotions and sensitivity, a graveyard or cemetery offers a more 'neutral' and traditional public location at which everyone feels welcome.

Sympathy for the bereaved likewise makes the incorporation of family memories into the portrayal and inscription more likely, especially if the statue is sited graveside. ${ }^{42}$ Where sculpture designs are developed from images supplied or chosen by the family, 
they may be more personal and less soccer specific. A monument's design and interpretative material commemorating a subject who has died suddenly mid-career is also likely to tend towards sanctification, because of the desire of other stakeholders 'not speak ill of the dead', the lack of a time period in which to put the subject's career into context, and even the possible absence of a sporting raison d'etre for the statue (e.g. career achievement or long service).

Additionally, the contemporaneity of the subject's playing career will impact upon design and interpretative material. Halbwachs, speaking of the creation of collective memory, claims that "the repetition engaged in various commemorative events and rituals is crucial in... creating a single, highly idealized, composite image." ${ }^{43}$ Soccer player statues almost exclusively depict their subjects in such an idealized way: as active players in their prime, shooting powerfully, dribbling languidly, holding a trophy aloft or posed authoritatively with foot on ball. In the (usually lengthy) period between a subject's retirement and portrayal, the repetition of both the specific flashbulb or video memories that many statue designs are based on and the career narratives that interpretative materials such as plaque inscriptions are drawn from have come to represent the subject in the collective memory of fans, teammates and even family.

Conversely, where sudden death has occurred during the subject's career, the time required for such a single idealised image to become cemented in the minds of teammates, fans and families has not been allowed. Multiple personal and collective memories of the subject will be fresh. Myth making will, of course, occur during a soccer player's career - but the extent to which it can become fixed is tempered by the 
possibility of it being supplanted. A statue to a player killed mid-career and erected soon after embodies future collective memory: as an almost-contemporary representation of the subject, it writes the narrative rather than copying it, and creates myths rather than recycling them. Whilst achievements may be recognised though the design and inscription, the memorialisation of the player is as much about what might have been.

We now consider two fêted yet ill-fated soccer players, from clubs of similar size, who achieved much at a young age and of whom much more was expected before an untimely death. Dragan Mance of Serbia (from the former Yugoslavia) and Antonio Puerta of Spain both died at the age of just 22, having appeared for their home city club at the highest level of domestic soccer whilst still in their teens. Each had already won major honours with their clubs, been capped by their country, and were considered as future international regulars. Following their death, both were swiftly commemorated in statue form.

\section{Dragan Mance and Antonio Puerta}

Dragan Mance debuted for FK Partizan Belgrade, one of the major soccer clubs of the former Yugoslavia (now Serbia), aged just 18, and rapidly became an immensely popular figure amongst the 'grobari' (translation: 'gravediggers'), as Partizan's notoriously volatile fans are known. His status was undoubtedly enhanced by his youthful good looks and prolific goal scoring feats (42 goals from 117 league appearances, including several celebrated strikes against fierce cross-city rivals Red Star Belgrade). ${ }^{44}$ Mance was killed in a road accident whilst he was travelling to training on September 3, $1985 .^{45}$ Two days later he was buried in Novo Groblje 
(translation: New Cemetery), Belgrade. A crowd of over 20,000 attended, including opponents and civic dignitaries as well as fans and teammates, lining the route to the graveside. According to Serbian daily newspaper Vecernje Novosti, there had not been a burial like this for a long time. Mance's coffin was borne by his teammates, who were dressed in their full home kit of black and white stripes. ${ }^{46}$

The collective memory of Dragan Mance has been created, shaped and continues to be represented by material, oral, musical and digital commemorations. A road close to FK Partizan's stadium has been named Dragan Mance Street; the club shop stocks Dragan Mance T-shirts; a documentary film has been recorded; photos and goal videos are showcased on FK Partizan fan websites; both a pop song and a folk song in traditional Serbian style have been composed in his honour. ${ }^{47}$ Most tellingly, FK Partizan fans, many of whom were born after his death, still proactively remember Mance at matches through banners and chants. They have established an annual award for the service to the club in his honour, and consider him their greatest ever player. ${ }^{48}$ A statue of Dragan Mance (Figure 3) was erected at the head of his grave in Novo Groblje, a year after his death.

Figure 3: The Statue of Dragan Mance, Novo Groblje, Belgrade (Photo by Dejan Zec) $<$ Figure 3 here>

By August 2007, Antonio Puerta had been with Sevilla FC for almost 14 years, working his way up through the club's youth system to be a first choice player in a team that had won the UEFA Cup (twice) and the Copa Del Rey since 2005 . $^{49}$ The wing-back suffered multiple cardiac arrests during Sevilla FC's first La Liga game of 
the 2007/08 season, a home fixture against Getafe, and died 3 days later in hospital. ${ }^{50}$ The underlying cause of death was a genetic heart muscle abnormality, a condition that has claimed the lives of several other prominent soccer players, including Cameroon's Marc Vivien Foé and Benfica's Hungarian striker Miklos Feher. ${ }^{51}$

Antonio Puerta has received a similar roll call of tributes to those bestowed upon Dragan Mance, including street naming and fan banners. ${ }^{52}$ An annual friendly match between Sevilla FC and another major Spanish club is held in his honour, with the winning team awarded the Antonio Puerta Trophy. ${ }^{53}$ His shirt number 16 has become iconised. Sevilla FC attempted to retire it, and it has been used in a number of commemorative gestures. For example, gate 16 at Sevilla's stadium has been named after Puerta, with the words "Puerta Hacia La Gloria" (translation: "door towards glory") placed above it, and the Antonio Puerta Trophy is a framed relief of the rear of his shirt with the 16 prominent. ${ }^{54}$ Furthermore, a statue of Antonio Puerta (Figure 4) was unveiled two and a half years after his death at Sevilla FC's training complex, the José Ramón Cisneros Palacios Sports Centre. ${ }^{55}$

Figure 4: The Statue of Antonio Puerta, José Ramón Cisneros Palacios Sports Centre, Sevilla (Photo by Jorge Bretos Santiago, Sevilla FC)

$<$ Figure 4 here>

\section{Statue development}

In the aftermath of Dragan Mance's death, both his family and FK Partizan fans lobbied for a statue to be erected by his grave. FK Partizan adopted the project, providing the majority of the finance, with the statue being sculpted by noted 
Yugoslavian artist Dragan Drobnjak. ${ }^{56}$ At the time, such a proposal was an extremely unusual honour to confer upon a soccer player. Mance's statue is a chronological outlier in the context of the world's soccer statuary, being within the first 20 subjectspecific examples. ${ }^{57}$ In the absence of any established soccer-specific memorialisation protocol involving statues at the time of Mance's death, its development is best explained by a national commemorative tradition of adding an image of the deceased to a grave. In September 1986, Dragan Mance's statue was unveiled. Footage of the occasion shows a large crowd of fans squeezed in around the adjacent gravestones, and a black and white striped cover being removed to reveal the statue. ${ }^{58}$

Although the Antonio Puerta statue was similarly conceived, it endured a rather more convoluted production process. A clamour from supporters for a statue to be erected in his honour was rapidly acknowledged by Sevilla FC, the club taking control of the commissioning process and paying for the project. ${ }^{59}$ An open competition to find a sculptor did not result in a satisfactory design, so in 2009 a second competition, limited to 7 noteworthy artists, was launched. ${ }^{60}$ A project committee, consisting of members of the soccer club, art professionals and professors from the faculty of Fine Arts in Seville, selected sculptor Constantino Gañán's design. ${ }^{61}$

A formal unveiling ceremony took place on April 27, 2010. The date itself was symbolic, falling exactly 4 years after Puerta's winning goal against Schalke that had started an unprecedented run of success for the club and established him as a club hero. At the ceremony, family, friends, teammates, club officials and local and national dignitaries were seated in rows close to the statue. Seated alongside and behind them were over a hundred children from Sevilla FC's soccer schools and youth 
system, dressed in identical soccer kits. Fans were held further back behind barriers. Puerta's girlfriend and son jointly unveiled the statue as triumphant music played. Speeches were made by his teammate Jesus Navas, the Secretary of State for Sports Jaime Lissavetzki, sculptor Gañán, and Hipólito Gutiérrez Espinoza, a child selected from Sevilla FC's soccer school. ${ }^{62}$

\section{Statue locations}

Dragan Mance's statue is located beside his grave in lot 108 of Novo Groblje, a large public cemetery lying just east of central Belgrade. Novo Groblje is the burial place for many thousands of ordinary citizens, and also has special areas for military personnel and distinguished citizens. Though Serbian sporting heroes have been buried in the distinguished citizen's lot - for example, basketball player Radivoje

Korać - Mance's grave site is in a regular citizen's area. ${ }^{63}$ Mance's plot is adjacent to a primary North-East to South-West path across the cemetery and nearby to an entrance gate, making it fairly prominent. Novo Groblje has no preferential connection to either FK Partizan or their rivals Red Star, and is over two miles from both stadia. As a location for a statue of an FK Partizan soccer player, it is both accessible and neutral.

Even when considered in the light of social custom, the addition of a statue to Mance's grave is an exceptional tribute. Financial resources typically limit grave iconography to a picture. Amongst the graves accompanying Mance in Novo Groblje, only around 25 feature a full body statue. Admittedly, compared to a typical public citizen, the potential funds for honouring a fêted soccer player are far larger, due to the extended 'family' of soccer club and fanbase, but the most notable fellow 
sportsman grave in the cemetery, that of basketball player Radivoj Korać who, like Mance, died mid-career in a car accident, is not accompanied by a statue. Elsewhere across Europe, we have identified just five other grave statues of soccer players (and three of managers or coaches). Only one of these statues is within the former Yugoslavia, and only one pre-dates Dragan Mance. Notably, three of these examples are of players who died during their careers. ${ }^{64}$

Though Antonio Puerta's statue was erected at a club specific location, it was not the stadium concourse, club museum or even within the grounds of Sevilla FC's stadium, Estadio Ramón Sánchez-Pizjuán. Instead, the club chose to site it at José Ramón Cisneros Palacios, their senior and youth team training centre, where Antonio Puerta had spent many days of his childhood and career. The complex consists of several pitches alongside a small stadium and headquarters building. This decision was made before a sculptor and design was chosen. ${ }^{65}$ The facility incorporates a soccer school for young local players, now renamed Escuela de Football Antonio Puerta. The statue is by the expansive car park. The facility lies beyond the edge of the city, in an exurban hinterland surrounded by arterial roads and golf courses. Though served by a nearby metro station, it is well away from residential areas. It is rare to find a statue of a soccer player at club premises away from their stadium, the most prominent examples existing in Brazil, where club headquarters are often some distance from playing facilities, and ground sharing is more prevalent. ${ }^{66}$

\section{Statue design}

Other grave statues of specific soccer players or managers around the world capture the subject in a posed, upright stance, cradling, or with foot resting on a ball. ${ }^{67}$ This 
suggests the prioritisation of conferring a sense of dignity to the deceased, and showing a respect for the sombre location by not 'playing' amongst the headstones. Dragan Mance's sculpture is a dramatic departure from such designs. It converts soccer fanaticism and flashbulb memory into secular material form within a religious setting. In a portrayal agreed upon by family, club and sculptor, the lauded FK Partizan prodigy kneels in his trademark celebratory pose having scored a goal, a singular celebration captured on many occasions. ${ }^{68}$ This specific iconography solidifies a collective memory that Mance himself was casting through repetition and reputation during his career. It has subsequently been recycled in other forms and locations, most notably in banners displayed at FK Partizan matches, the aforementioned pop song dedicated to Mance (which contains the line "Na kolenima, klizi po travi, podiže ruke, golove slavi” - translation: "On his knees, he slides through the grass, he raises his hands, and celebrates goals"), the design of the trophy awarded by FK Partizan fans for contribution to the club, and in a large mural under the Grmeč flyover on the Belgrade to Novi Sad motorway, the site of Mance's death. ${ }^{69}$

By making this image permanent, the statue also writes the narrative of Dragan Mance in a deeper, multivalent way. Mance is captured as a goalscorer. The act of scoring a goal is itself heroic, and the pose cast reiterates the triumphant moment. More knowledgeable or longstanding FK Partizan fans may relate the celebration to a specific goal scored by Mance - potentially even the one vs Red Star Belgrade in 1984 from which the image was sculpted - codifying a specifically FK Partizan and partisan heroism and heritage. ${ }^{70}$ Further, a goal celebration is an interaction between a player and the fans. By portraying this through the statue design and mediating it physically through the low height and lack of pedestal, this monument offers FK Partizan 
supporters a connection with Dragan Mance. Rather than defining Mance as a dislocated celebrity soccer player, as a player of his ability and success might have become in the modern era, he is instead affirmed as part of the FK Partizan community.

Antonio Puerta's statue is more typical of many other soccer player statues around the world, capturing the player running forward with the ball at his feet. The design highlights Puerta's athletic traits, accentuating speed and elegance. Puerta's shirt number 16 and his name are prominently embossed. Sculptor Constantino Gañán had full control of the design and chose to compose it from multiple images rather than a specific photo. Gañán comments how the tragic circumstances influenced this portrayal towards the heroic:

"I was tempted to represent him while making a big effort, though it seemed inconvenient given his dramatic death, therefore when modelling (the sculpture) I consciously walked away from being too naturalistic, to represent a player closer to the figure of hero who is always idealized, I respected his lean build and wanted to highlight his peculiar way to run when the ball was given to him." ${ }^{\text {71 }}$

The bronze sculpture is raised on a three foot high concrete plinth, with stepped wings either side of the statue. Though a smaller, higher plinth would create greater prominence for the statue, Gañán designed the pedestal with the aim of making the statue more accessible, particularly to the children who attend soccer schools at the 
complex - the wings act as benches enabling groups or teams of junior players to pose and be photographed alongside Puerta's statue. ${ }^{72}$

Gañán reiterated the theme of inspiring the next generation of soccer players by deliberately orienting the statue to the East, relating the rising of the sun to the new soccer dawns created by Sevilla FC's vaunted youth system, through which Antonio Puerta was developed. ${ }^{73}$ This arrangement links the sculpture both to the location type, and also to how Sevilla FC specifically shaped Puerta's life.

\section{Statue inscriptions and motifs}

Grave statues of soccer players do not usually feature dramatic outward visual projections of club allegiance. Dragan Mance's graveside is the exception. The bronze plaque features an FK Partizan badge accompanied by a minimal inscription, which translates as:

\section{DRAGAN MANCE}

1962-1985 FAMILY

\section{FK PARTIZAN MANCE}

Dragan Mance's status as an FK Partizan Belgrade player is elevated to the same level as his family name; FK Partizan forms a wider family. The statue itself portrays Mance resplendent in FK Partizan's famous stripes. However, neither the plaque nor statue design are the primary visual Partizan-specific motifs. The small plaque is placed at the foot of the statue, and is often hidden by flowers placed upon the grave. The bronze sculpture is only faintly patinated to indicate a striped shirt, and identifying the club badge requires close inspection. Instead, the most obvious statement of Mance's role and allegiance comes from the marble tombstone that 
fronts the grave. Constructed in FK Partizan's black and white stripes and resembling a soccer shirt, it bears a number 9, the traditional number for a forward player, and that worn by Mance. In a city where two large and successful clubs are embedded into popular consciousness, even a cursory glance at this imagery makes it obvious that the person buried here was an FK Partizan striker.

Antonio Puerta's statue lacks a similar transparent club-specific visual marker. Like Dragan Mance he has been sculpted in his club shirt, but this is only visible from close range and from one side of the statue: it would be possible to pass by on the other side and miss this detail. The plaque inscription refers to Puerta's famous goal against Schalke, interpreting it not so much as a personal triumph but in the context of launching a period of success for the club. Translated, the full inscription reads as

\section{ANTONIO PUERTA}

$1984-2007$

YOUR LEFT FOOT GIFTED US WITH A DREAM THAT CHANGED

OUR LIVES, AS IT THEN BEGAN ONE OF THE MOST GLORIOUS

STAGES OF OUR CLUB. THANK YOU ANTONIO.

FROM ALL YOUR FANS.

The plaque reinforces a message of tangible club achievement by including silhouettes of the 5 trophies won by Sevilla FC teams featuring Antonio Puerta in the 2005/06 and 2006/07 seasons.

\section{Beyond mourning: meanings and comparisons}


The monuments to Dragan Mance and Antonio Puerta share much in common in the scenarios that produced them. Both were young soccer players who had achieved much in their brief careers, only to have them cut short in the most tragic way. Their deaths were and continue to be marked through a variety of material artefacts and rituals, the similarity of which indicate the existence of a 'grammar' of soccer-related grieving, which as suggested by Russell extends across national and cultural boundaries. $^{74}$

These tributes include statues that were, initially at least, places of myth creation as opposed to re-creation or recycling. Both monuments continue to be shrines that contribute to the preservation, communication and accretion of collective memory of their subjects. This effect is transmitted directly through the sculpted image, and indirectly via the site of reception and associated rituals, such as reinforcing the iconicity of their subject's shirt numbers. Contrary to what might have been expected given the tragic scenarios that gave rise to their development, the influence of family members' personal memories into the respective designs and inscriptions is not overly prominent in either statue, their contribution being more that of approval than active input. Both portrayals are centred around the subject's involvement in and contribution to soccer.

However, any visitor to both of these memorials would be struck by the profound differences in their designs, locations and presentation styles. While the celebratory pose of the goal-scoring Mance contrasts to that of Puerta, a defensive player who is calmly in control of the ball, it is also true that Puerta's most memorable moment in a Sevilla FC shirt was his famous goal against Schalke. The choices made in these 
depictions reflect a combination of differences in memorialisation custom, clubspecific and soccer cultures, and the possibly the era in which each statue was unveiled.

Dragan Mance's statue is fundamentally an icon of fan culture, forging his place in the collective memory of FK Partizan supporters through recalling the glorious but ephemeral moments he shared with them. The statue design, which has become the primary visual motif for remembering Dragan Mance through its recycling in banners, trophies and murals, echoes and promotes a soccer culture rich in spontaneity and overt displays of passion and interaction between players and fans. This culture is reflected by the lack of physical and societal elevation of Dragan Mance's memorial he remains a grounded, local hero - and in the relatively informal unveiling ceremony, just as much as the raucous and febrile atmosphere still found in Stadion Partizana.

The chosen site of reception also reflects the mourning of a very tribal hero in a public, non-soccer, non-club-specific space located within a divided city. Appropriating such a potentially contested public space requires staking a visual claim to it. Mance's statue has brought with it the excitement, colours and motifs of the secular religion of soccer (and FK Partizan in particular), taking them from the stadium to demarcate a Partizan space within a public site of mourning imbued with more traditional religious iconography. Siting the statue at an accessible location, yet one that requires a deliberate act of visitation has created a specific place of pilgrimage for followers of FK Partizan, with each journey reinforcing this annexation of territory. The grobari have moved in to the graveyard. 
Conversely, Antonio Puerta's statue is not only in a club space, but in a segregated, semi-private site rather than the contested ownership of an oft-visited stadium concourse, the more typical home for soccer player statues. Future collective memories evoked by both Puerta's statue and Estadio Ramón Sánchez Pizjuán are defined by this placement decision. In erecting the statue away from their stadium, Sevilla FC have avoided providing fans with a visual reminder of the link between Puerta's death and their home turf.

Instead, Puerta's statue's location at Sevilla FC's training ground separates it from the club's fans both in its distance from the city and the stadium, and also by the site's purpose, which is to coach and develop players. This location, combined with the choreographed unveiling ceremony with its central role for child soccer players, the action design of the statue, the inscription referencing club achievement, and above all the interaction with the location, constructs a club-ordered and clearly defined narrative revolving around Sevilla FC's youth scheme, Puerta's life within it, the club's ability to develop its own talent, and the resulting impact on club achievements. Whilst Sevilla FC fans have created their own rituals for remembering Antonio Puerta, his statue is not an integral part of the representation of Puerta to them. Instead, it is an icon for eager and ambitious young players, proselytising and celebrating the success of the organisational strength, teamwork and player development ethos of Sevilla FC. The training ground is fixed as Puerta's symbolic home, with his rise to first team status and the trophies that it brought extolling the benefits of hard work and dedication to the young soccer players learning their craft there. Furthermore, the cemetery location of Mance's monument places him as a 
tragic hero, yet it is only the dates on Antonio Puerta's statue plaque that communicate his demise. Dragan Mance's statue overtly takes soccer to a place of mourning, yet Antonio Puerta's memorial has not brought mourning to a place of soccer.

\section{Acknowledgements}

The authors would like to thank Constantino Gañán, Dušan Mihajilovic, James Moor and Dejan Zec for their invaluable help in researching this article. 


\section{Notes}

1. Armstrong, 'Memorializing in Sport: A Comparison of the Responses to the Deaths of Dale Earnhardt and Darryl Kile'; Sherman, The Construction of Memory in Interwar France, 186.

2. Mol, Identity and the Sacred, 206.

3. Figurative statues portray a lifelike representation of a human subject. They are at least close to life-size and depict the body; as opposed to statuettes or figurines, which are small enough to be easily lifted, or busts, which depict just head and shoulders. Within this article the terms soccer statues or statuary are used to define existing or planned statues of specific soccer players, managers, chairmen, owners or founders, erected in tribute to their contribution within the sport, and accessible to the general public.

4. Between January 2013 and March 2014, the authors constructed a database of existing statues of soccer players, managers, and chairmen as part of a wider project into commemoration in sport, which they have continued to maintain and update. Data and images were obtained through a literature, archival and online search, and via interviews with sculptors and project organisers. Variables collected included the precise location, date of unveiling, design type (broadly classified as 'action', 'posed' or 'triumph'), the full plaque or plinth inscription, and the identity of the statue project promoters and funders, as well as further demographic and performance information on the subjects depicted. As of April 1st 2017 the authors had identified 286 in situ statues or statue groups of specific soccer players, depicting 356 distinct players. In addition 45 statues depicting managers, 18 statues depicting chairmen/founders/executives and 177 statues depicting anonymous players or fans have been identified. Note that some statues feature more than one subject, and some subjects have been honoured on multiple occasions. The database is complete and accurate to the best of our knowledge. Since April 2014 the primary elements of the database (the statue location, sculptor, unveiling date, inscription and photos of the statue showing the design) have been publically available through the project website at http://www.sportingstatues.com.

5. Savage, 'The Politics of Memory: Black Emancipation and the Civil War Monument'; Prown, 'Mind in Matter: An Introduction to Material Culture Theory and Practice', 135; Dwyer, 'Symbolic Accretion and Commemoration'. 
6. Huyssen, Twilight Memories: Marking Time in a Culture of Amnesia.

7. Pre-eminent examples of research on sports statues include Smith, 'Frozen Fists' and Osmond, Phillips and O'Neill, "Putting up your Dukes”. For a soccer-specific review, see Stride, Wilson and Thomas, 'From pitch to plinth: documenting the UK's football statuary'.

8. Morris, Sinners, Lovers, and Heroes: An Essay on Memorializing in Three American Cultures, 40.

9. Stride, Thomas and Wilson, 'The Sporting Statues Project', http://www.sportingstatues.com.

10. E. Runia, 'Burying the Dead, Creating the Past', 313.

11. Doss, Memorial Mania: Public Feeling in America, 50.

12. Ibid, 51 .

13. Stevens and Franck, Memorials as Spaces of Engagement: Design, Use and Meaning.

14. Taylor, 'Football History and Memory: The Heroes of Manchester United', 36.

15. In the UK, based upon information gathered from statue project organisers and sculptors regarding statues erected between 2001 and 2010, the median cost of a single full body soccer player bronze statue of at least three-quarter size was approximately $£ 65,000$ UK pounds. See Stride, Wilson and Thomas, 'From pitch to plinth: documenting the UK's football statuary', 6.

16. Pascal, Sprott and Muehling, 'The Influence of Evoked Nostalgia on Consumers' Responses in Advertising: An Exploratory Study'; Seifried and Meyer, 'Nostalgia-Related Aspects of Professional Sports Facilities: A Facility Audit of Major League Baseball and National Football League Strategies to Evoke the Past'; Stride, Wilson and Thomas, 'Honouring Heroes by Branding in Bronze'; Ramshaw and Gammon, 'More than just Nostalgia? Exploring the Heritage/Sport Tourism Nexus'; Funk and James, 'Consumer Loyalty: The Meaning of Attachment in the Development of Sport Team Allegiance'; Lasaleta, Sedikides and Vohs, 'Nostalgia Weakens the Desire for Money'.

17. Bale, Sport, Space and the City; Stride, Wilson and Thomas, 'Honouring Heroes by Branding in Bronze'; Ramshaw and Gammon, 'More than just Nostalgia?'

18. Dixon, Consuming Football in Late Modern Life, 59. Bale, Sport, Space and the City. 79.

19. Walsh and Giulianotti, 'This Sporting Mammon: a Normative Critique of the Commodification of Sport'.

20. Guilianotti, 'Supporters, Followers, Fans and Flaneurs', 33. 
21. Stride, Thomas and Wilson, 'The Sporting Statues Project', http://www.sportingstatues.com.

22. For example, in the UK, statues of sportsmen or sportswomen from team sports are most likely to be found at a stadium or sports facility (54\%) with a smaller percentage at civic sites. Conversely athletes from individual sports are more likely to be found at civic sites (64\%). See http://www.sportingstatues.com for precise locations.

23. Prominent examples are the United States' Wilma Rudolph (in Clarksville, Tennessee), Australia's Betty Cuthbert (Melbourne), or the Netherlands' Fanny Blankers-Koen in Rotterdam. Rudolph's statue is covered in detail in: Smith, 'Mapping America's Sporting Landscape: A Case Study of Three Statues'; Cuthbert's statue is sited at the MCG and was unveiled in (2003); Blankers-Coen is depicted in two statues, one sited in Rotterdam (unveiled 2005), the other in her home town of Hengelo (unveiled 2007).

24. An anonymous female soccer player is depicted in Christel Lechner's Alltagsmenschen (trans. Everyday People) statue in Baden-Württemberg, Germany. Female fans appear in fan statues in Kaiserslautern, (Germany), at RCD Espanyol (Spain), and at Sunderland FC (UK).

25. Schuman and Scott, 'Generations and Collective Memories'.

26. Stride et al, 'Modeling Stadium Statue Subject Choice in US Baseball and English Soccer'.

27. For example, in Spain and Portugal there are 17 statues of specific soccer players as of 1 April 2017. In 59\% of cases the subject was alive when the statue was unveiled. The equivalent percentages for Argentina and Brazil (47 statues, 74\%) and East Asia (China, Japan, Indonesia; 9 statues or statue groups, $55 \%$ ) are similar. Likewise in US baseball: of the 256 statues depicting specific players, $131(51 \%)$ were unveiled when the player was still alive.

28. Only 3 of the 34 soccer player statues sited in Eastern Europe were erected when the subject was alive.

29. If the statue group depicting the entire Chinese squad that successfully qualified for the 2002 FIFA World Cup is counted as a single instance, just 22 examples of active-player depiction exist. These include such luminaries as Pele (twice), Johann Cruyff, Thierry Henry, Lionel Messi, Edwin Van Der Sar, Gabriel Batistuta, Andres Iniesta, David Silva, Samuel Eto'o and Juan Roman Riquelme. The statues of Batistuta and Riquelme were unveiled near or at their 'home' stadiums whilst they still represented the club that played there. For further details on each statue see the Sporting Statues Project database at http://www.sportingstatues.com. 
30. Russell, 'We All Agree, Name the Stand after Shankly': Cultures of Commemoration in Late Twentieth-Century English Football Culture', 2.

31. Corkill and Moore, "The Island of Blood': Death and Commemoration at the Isle of Man TT Races', 249.

32. Guilianotti, A Sociology of the Global Game, 21-22.

33. Huggins, 'Death, Memorialisation and the Victorian Sporting Hero'; Corkill and Moore, 'The Island of Blood'; Armstrong, 'Memorializing in Sport'; Foster and Woodthorpe, 'A Golden Silence? Acts of Remembrance and Commemoration at U.K. Football Games'.

34. M. McGuinness, 'The Canonisation of Common People: Memorialisation and Commemoration in Football'; Woolridge, 'They Shall Not Grow Old': Mourning, Memory and the Munich Air Disaster of 1958'; Russell, 'We All Agree'.'; Herzog, Memorialkultur Im Fußballsport: Medien, Rituale Und Praktiken Des Erinnerns, Gedenkens Und Vergessens.

35. Wangen, Die Gräber Der Götter: Fußballhelden Und Ihre Letzte Ruhestätte; Cardorff and Böttger, Der Letzte Pass. Fußballzauber in Friedhofswelten - Zuschauer Erwünscht; Sharpe, The Final Whistle: Midfield Fare Wells, Sudden Deaths and Other Strange but True Passings from Football's History.

36. Goldblatt, The Game of Our Lives: The Meaning and Making of English Football.

37. Fordyce, 'Phillip Hughes', http://www.bbc.co.uk/sport/0/cricket/30236817 [accessed 12 January 2016]

38. Huggins and O'Mahony, The Visual in Sport, Sport in the Global Society - Historical Perspectives.

39. Mitchell, 'Monuments, Memorials, and the Politics of Memory', 443.

40. McGuinness, 'The Canonisation of Common People', 212; R. Penn, 'Cathedrals of Sport: Football Stadia in Contemporary England'; A. Edge, Faith in Our Fathers.

41. M. Huggins, 'Gone but Not Forgotten: Sporting Heroes, Heritage and Graveyard Commemoration', 481.

42. Ibid, 488.

43. Halbwachs, On Collective Memory.

44. reprezentacija.rs, 'Mance, Dragan', http://www.reprezentacija.rs/index.php/statistika/reprezentativci/1253 [accessed 3 March 2014]. 
45. Preljic, 'Poginuo Mance', Politika Ekspres.

46. Unattributed, 'Tuga Sa 'Juga'’; tribuna.sports.ru, ‘Трибуна Блог',

http://www.sports.ru/tribuna/blogs/serbian/229955.html[accessed 5 March 2014].

47. underPFC, 'Tragična Smrt Dragana Mancea (Gusle)' (2012). This contemporary pop song can be heard at https:/www.youtube.com/watch?v=PulJ-RccwjM[accessed 5 March 2014]; mudrac3srpska, 'Dragan Mance Pesma' (2009). This traditional Serbian folk song can be heard at https:/Www.youtube.com/watch?v=aBVtn5VG0SI [accessed 5 March 2014]; FK-PartizanBelgrade, '2353 T Shirt Fc Partizan 'Dragan Mance - the Legend Is Alive' - Grey’, http://www.partizanshop.rs/user/item.jsp?f_item_id=29937\&f_cat_id=2413\&f_shop_id=54\&f_la ng_id=2 [accessed 5 March 2014]; Paunovic, 'Mance' (Belgrade: Union film, 1990); Kovacevic, 'Dragan Mance Dobio Ulicu', http://novosti.rs/vesti/beograd.74.html:346660-Dragan-Mancedobio-ulicu [accessed 12 March 2014].

48. Moor, Grobar: Partizan Pleasure, Pain and Paranoia: Lifting the Lid on Serbia's Undertakers. For images of banners commemorating and celebrating Dragan Mance see, for example: rts.rs, 'Ulica Za Mancea U Zemunu', http://www.rts.rs/page/sport/sr/story/36/Fudbal/766774/Ulica+Za+Mancea+u+Zemunu.html [accessed 3 March 2014]; Bunić, 'Dragan Mance Uskoro Dobija Ulicu Kod Stadiona Partizana',

http://www.blic.rs/Vesti/Beograd/238372/Dragan-Mance-uskoro-dobija-ulicu-kod-stadiona-
Partizana [accessed 3 March 2014].

49. Haurie, 'El Autor Del 'Gol Que Cambió La Vida De Los Sevillistas', http://www.elmundo.es/elmundo/2007/08/28/obituarios/1188312804[accessed 3 March 2014].

50. Fuertes, 'Muere Antonio Puerta', http://deportes.elpais.com/deportes/2007/08/28/actualidad/1188285718_850215.html [accessed 3 March 2014].

51. Press-Association, 'Footballer Foe Dies During Game', www.theguardian.com/world/2003/jun/26/football; Ashdown, 'Benfica Striker Dies after Heart Attack on Pitch', http://www.theguardian.com/football/2004/jan/26/newsstory.sport4 [accessed 5 March 2014].

52. Alvarado to jesusalvarado.com, http://www.jesusalvarado.com/2012/12/27/antonio-puerta-yatiene-su-calle/ [accessed 12 March 2014];.adelante-antifa to adelante-antifa, 
http://adelanteantifa.blogspot.co.uk/2013/11/sevilla-fc-ud-almeria-trofeo-antonio.html [accessed 3

March 2014].

53. Más-fútbol, 'El Sevilla Se Enfrentará Al Málaga En El I Trofeo Antonio Puerta’, http://futbol.as.com/futbol/2008/08/06/mas_futbol/1217973624_850215.html [accessed 9 March 2014].

54. marca.com, 'Del Nido Anuncia Que El Sevilla Retirará El Dorsal '16', http://archivo.marca.com/edicion/marca/futbol/1a_division/sevilla/es/desarrollo/1031086.html J.I. Macias to Desde Gol Sur De Nervion, http://desdegolsurdenervion.blogspot.co.uk/2011/08/puertas-del-estadio.html [accessed 3 March 2014]; Departamento-Prensa-Sevilla-F.C., 'El Trofeo Antonio Puerta Ya Está En El Ramón Sánchez Pizjuán', http://sevillafc.es/nuevaweb/actualidad/noticias/11660 [accessed 5 March 2014].

55. Departamento-Prensa-Sevilla-F.C., 'La Estatua De Puerta, La Estatua De Un Mito', http://www.sevillafc.es/nuevaweb/comprometidos/historia/25205 [accessed 12 March 2014].

56. Goran Mance, correspondence with the first author via a translator, February 2014.

57. Stride, Thomas and Wilson, 'The Sporting Statues Project'.

58. Speed, 'Dragan Mance (Dokumentari Film)', https:/www.youtube.com/watch?v=JcXGJZ4e87U [accessed 26 March 2014].

59. For example: Rojadirecta, 'Propuestas Para Recordar a Antonio Puerta', http://forum.rojadirecta.es/showthread.php?23156-Propuestas-para-recordar-a-AntonioPuerta\&s=fb2c4b26c9fc9f47067aaec97783091c [accessed 3 March 2014]; A. Rodriguez to Mundo Sevillista2007, http://www.mundosevillista.com/blog/?p=420 [accessed 5 March 2014].

60. Constantino Gañán, telephone interview and correspondence with third author, February 2014; Departamento-Prensa-Sevilla-F.C., 'El Concurso De La Escultura De Antonio Puerta Queda Desierto', http://sevillafc.es/nuevaweb/actualidad/noticias/13076 [accessed 3 March 2014].

61. Constantino Gañán, telephone interview and correspondence with third author, February 2014.

62. Departamento-Prensa-Sevilla-F.C., 'Acto Escultura a Antonio Puerta En Ciudad Deportiva Sfc 27 04 10’; Departamento-Prensa-Sevilla-F.C., 'La Estatua De Puerta, La Estatua De Un Mito’, http://www.sevillafc.es/nuevaweb/comprometidos/historia/25205 [accessed 3 March 2014]; 
Quequeno-Sevilla, 'Queueno: Antonio Puerta Ciudad Deportiva Monumento', https:/www.youtube.com/watch?v=8RQvbGx0M5A [accessed 5 March 2014].

63. Pogrebne-Usluge-Beograd, 'Radivoje Korać', http://www.beogradskagroblja.rs/page/famouspersons/100132/cnt/radivoje-kora\%C4\%87.en-GB.htm [accessed 3 March 2014]; 'Dragan Mance', http://www.beogradskagroblja.rs/page/famous-persons/100162/cnt/dragan-mance.enGB.htm [accessed 3 March 2014].

64. Other soccer players with half-life-size or larger grave statues that we have identified include three other Eastern European players who died suddenly during their careers, CSKA Moscow's Sergei Perkhun, Croatian goalkeeper Ivan Turina, and Florin Piturca of FCM Turnu Severin, Romania - along with former Germany captain Fritz Walter and an English lower league player Jim Sanders. Three Ukrainian managers or coaches - Dynamo Kyiv‘s Valery Lobanovsky and Valyantsin Byalkevich, and Dnipro's Evgeny Kucherevsky - have also been honoured in this way.

65. Constantino Gañán, telephone interview and correspondence with third author, February 2014.

66. For example, the statue of Brazilian striker Zico erected in his honour by his club side CR Flamengo, is sited at the club's headquarters building. Flamengo, in common with many other Brazilian clubs, have traditionally hired large municipal stadia in which to play home matches rather than owning their own ground.

67. Photographs of each statue can be viewed at the Sporting Statues Project database http://www.sportingstatues.com.

68. Goran Mance, correspondence with the first author via a translator, February 2014.

69. mudrac3srpska, 'Dragan Mance Pesma.' The Dragan Mance Award trophy design is pictured here: izaberipartizan.com, http://casopis.izaberipartizan.com/v2/galerija.php?pcId=96\&page=1\# [accessed 3 March 2014]. An example of a banner with the same image as the statue can be found here: Rosić and Miladinović, 'Legenda Živi’, http://www.pressonline.rs/vesti/Presspedia/132127/legenda-zivi.html [accessed 3 March 2014]. The mural on the Belgrade to Novi Sad highway is pictured here: partizanbeograd.net, http://www.partizanbeograd.net/2013/09/blog-post_3.html [accessed 3 March 2014].

70. Goran Mance, correspondence with the first author via a translator, February 2014. Though Mance always celebrated with the knee slide and raised arms depicted by the statue, the sculpture 
was based on a specific Mance celebration following having scored Partizan's first goal in a 2-1

win vs Red Star Belgrade in 1984. See http://www.youtube.com/watch?v=nDKbRasFGC4

[accessed 3 March 2014].

71. Constantino Gañán, telephone interview and correspondence with third author, February 2014.

72. Ibid.

73. Ibid.

74. Russell, “We All Agree"”.

\section{Bibliography}

adelante-antifa, 14 November 2013, http://adelanteantifa.blogspot.co.uk/2013/11/sevilla-fc-ud-almeria-trofeoantonio.html.

Alvarado, J. to jesusalvarado.com, 27 December 2007, http://www.jesusalvarado.com/2012/12/27/antonio-puertaya-tiene-su-calle/.

Armstrong, E. 'Memorializing in Sport: A Comparison of the Responses to the Deaths of Dale Earnhardt and Darryl Kile', Sociology of Sport Online 6, no. 2 (2003).

Ashdown, J. 'Benfica Striker Dies after Heart Attack on Pitch', The Guardian Online, 26 January 2004, http://www.theguardian.com/football/2004/jan/26/newsstory.sport4.

Bale, J. Sport, Space and the City. London: Routledge, 1993.

Bunić, O. 'Dragan Mance Uskoro Dobija Ulicu Kod Stadiona Partizana', Blic online, 28 February 2011, http://www.blic.rs/Vesti/Beograd/238372/Dragan-Mance-uskoro-dobija-ulicu-kod-stadiona-Partizana.

Cardorff, P. and C. Böttger, Der Letzte Pass. Fußballzauber in Friedhofswelten - Zuschauer Erwünscht. Göttingen: Die Werkstatt, 2005.

Corkill, C. and R. Moore. "The Island of Blood': Death and Commemoration at the Isle of Man TT Races', World Archaeology 44, no. 2 (2013): 248-62.

Departamento-Prensa-Sevilla-F.C. Acto Escultura a Antonio Puerta En Ciudad Deportiva Sfc 2704 10. Sevilla: Sevilla FC, 2010.

Departamento-Prensa-Sevilla-F.C.. 'El Concurso De La Escultura De Antonio Puerta Queda Desierto', Sevilla FC, 27 January 2009, http://sevillafc.es/nuevaweb/actualidad/noticias/13076.

Departamento-Prensa-Sevilla-F.C.. 'El Trofeo Antonio Puerta Ya Está En El Ramón Sánchez Pizjuán', Sevilla FC, 21 August 2008, http://sevillafc.es/nuevaweb/actualidad/noticias/11660.

Departamento-Prensa-Sevilla-F.C.. 'La Estatua De Puerta, La Estatua De Un Mito', Sevilla FC, 28 April 2010, http://www.sevillafc.es/nuevaweb/comprometidos/historia/25205.

Dixon, K. Consuming Football in Late Modern Life. Aldershot: Ashgate, 2013.

Doss, E. Memorial Mania: Public Feeling in America. University Of Chicago Press: Chicago, 2012.

Dwyer, O. J. 'Symbolic Accretion and Commemoration', Social \& Cultural Geography 5, no. 3 (2004): 419-35.

Edge, A. Faith in Our Fathers. Edinburgh: Mainstream, 1999.

FK-Partizan-Belgrade. '2353 T Shirt FC Partizan "Dragan Mance - the Legend Is Alive" - Grey', FK Partizan Belgrade, http://www.partizanshop.rs/user/item.jsp?f_item_id=29937\&f_cat_id=2413\&f_shop_id=54\&f_lang_id=2.

Football's Fallen, http://footballsfallen.wordpress.com. 
Fordyce, T. 'Phillip Hughes: Why does a death in sport hit us so hard?', bbc.co.uk, 27 November 2014, http://www.bbc.co.uk/sport/0/cricket/30236817.

Foster, L. and K. Woodthorpe. 'A Golden Silence? Acts of Remembrance and Commemoration at U.K. Football Games', Journal of Sport and Social Issues 36, no. 1 (2012): 50-67.

Fuertes, S. F. 'Muere Antonio Puerta', El Pais, 28 August 2007, http://deportes.elpais.com/deportes/2007/08/28/actualidad/1188285718_850215.html.

Funk, D. C. and J. D. James. 'Consumer Loyalty: The Meaning of Attachment in the Development of Sport Team Allegiance', Journal of Sport Management 20, no. 2 (2006): 189-217.

Goldblatt, D. The Game of Our Lives: The Meaning and Making of English Football. London: Penguin, 2015.

Guilianotti, R. A Sociology of the Global Game. Cambridge: Polity Press, 1999

Guilianotti, R. 'Supporters, Followers, Fans, and Flaneurs: A Taxonomy of Spectator Identities in Football', Journal of Sport and Social Issues 26, no. 1 (2002) 25-46.

Halbwachs, M. On Collective Memory, trans. L. Coser. Chicago: University of Chicago Press, 1992.

Haurie, L. 'El Autor Del 'Gol Que Cambió La Vida De Los Sevillistas', elmundo.es, 28 August 2007, http://www.elmundo.es/elmundo/2007/08/28/obituarios/1188312804.

Herzog, M. Memorialkultur Im Fußballsport: Medien, Rituale Und Praktiken Des Erinnerns, Gedenkens Und Vergessens. Stuttgart: Kohlhammer, 2013.

Huggins, M. 'Death, Memorialisation and the Victorian Sporting Hero', The Local Historian 38, no. 4 (2008): 257-65.

Huggins, M. 'Gone but Not Forgotten: Sporting Heroes, Heritage and Graveyard Commemoration', Rethinking History: The Journal of Theory and Practice 16, no. 4 (2012), 479-95.

Huggins, M. and M. O'Mahony. The Visual in Sport, Sport in the Global Society - Historical Perspectives. London: Routledge, 2011.

Huyssen, A. Twilight Memories: Marking Time in a Culture of Amnesia. London: Routledge, 1995.

izaberipartizan.com to Izaberi Partizan Casopis, 30 August 2009,

http://casopis.izaberipartizan.com/v2/galerija.php?pcId=96\&page=1\#.

Kovacevic, M. T. 'Dragan Mance Dobio Ulicu', Novosti Online, 26 September 2011, http://novosti.rs/vesti/beograd.74.html:346660-Dragan-Mance-dobio-ulicu.

Lasaleta, J. D., C. Sedikides, and K. D. Vohs. 'Nostalgia Weakens the Desire for Money', Journal of Consumer Research 41, No. 3 (2014): 713-729.

McGuinness, M. 'The Canonisation of Common People: Memorialisation and Commemoration in Football', in Sport, History, and Heritage: Studies in Public Representation, ed. J. Hill, K. Moore, and J. Wood. Woodbridge: Boydell Press, 2012.

Macias, J. I. to Desde Gol Sur De Nervion, 6 August 2011,

http://desdegolsurdenervion.blogspot.co.uk/2011/08/puertas-del-estadio.html.

marca.com. 'Del Nido Anuncia Que El Sevilla Retirará El Dorsal '16', marca.com, 1 September 2007, http://archivo.marca.com/edicion/marca/futbol/1a_division/sevilla/es/desarrollo/1031086.html.

Más-fútbol. 'El Sevilla Se Enfrentará Al Málaga En El I Trofeo Antonio Puerta', Más fútbol, 6 August 2008, http://futbol.as.com/futbol/2008/08/06/mas_futbol/1217973624_850215.html.

Mitchell, K.. 'Monuments, Memorials, and the Politics of Memory', Urban Geography 24, no. 5 (2003), 442-459.

Mol, H. Identity and the Sacred. Oxford: Blackwell, 1976.

Moor, J. Grobar: Partizan Pleasure, Pain and Paranoia: Lifting the Lid on Serbia's Undertakers. Worthing: Pitch Publishing, 2013.

Morris, R. Sinners, Lovers, and Heroes: An Essay on Memorializing in Three American Cultures. Albany: State University of New York Press, 1997. 
mudrac3srpska. 'Dragan Mance Pesma' (2009). https://www.youtube.com/watch?v=aBVtn5VG0SI.

Osmond, G., M. G. Phillips and M. O'Neill, “"Putting up your Dukes”: Statues social memory and Duke Paoa Kahanamoku', The International Journal of the History of Sport 23, no. 1 (2006), 82-103.

Pascal, V. J., D. E. Sprott and D. D. Muehling. 'The Influence of Evoked Nostalgia on Consumers' Responses in Advertising: An Exploratory Study', Journal of Current Issues and Research in Advertising 24 (2002): 39-49.

Paunovic, A. Mance (Belgrade: Union film, 1990)

Penn, R. 'Cathedrals of Sport: Football Stadia in Contemporary England', in Soccer Review, ed. Patrick Murphy and Ivan Waddington. Leicester: Anchorprint Groupt Ltd., 2005.

Pogrebne-Usluge-Beograd. 'Radivoje Korać', http://www.beogradskagroblja.rs/page/famouspersons/100132/cnt/radivoje-kora\%C4\%87.en-GB.htm.

Preljic, B. 'Poginuo Mance', Politika Ekspres, 3 September 1985.

Press-Association. 'Footballer Foe Dies During Game', The Guardian Online, 26 June 2003, www.theguardian.com/world/2003/jun/26/football.

Prown, J. D. 'Mind in Matter: An Introduction to Material Culture Theory and Practice', Winterthur Portfolio 17, no. 1 (1982): 1-19.

Quequeno-Sevilla. 'Queueno: Antonio Puerta Ciudad Deportiva Monumento ", ed. Quequeno Sevilla (Sevilla: Quequeno Sevilla, 2010), https://www.youtube.com/watch?v=8RQvbGx0M5A.

Ramshaw, G. and S. Gammon. 'More than just Nostalgia? Exploring the Heritage/Sport Tourism Nexus', Journal of Sport \& Tourism, 10, no. 4 (2005): 229-241.

reprezentacija.rs. 'Mance, Dragan', http://www.reprezentacija.rs/index.php/statistika/reprezentativci/1253.

Rodriguez, A. to Mundo Sevillista2007, 7 September 2007, http://www.mundosevillista.com/blog/?p=420 .

Rojadirecta. 'Propuestas Para Recordar a Antonio Puerta', 29 August 2007,

http://forum.rojadirecta.es/showthread.php?23156-Propuestas-para-recordar-a-Antonio-

Puerta\&s=fb2c4b26c9fc9f47067aaec97783091c.

Rosić, B. and V. Miladinović. 'Legenda Živi', Online Media Press, 5 September 2010, http://www.pressonline.rs/vesti/Presspedia/132127/legenda-zivi.html.

rts.rs. 'Ulica Za Mancea U Zemunu', Radio Televizija Srbije, 17 September 2010, http://www.rts.rs/page/sport/sr/story/36/Fudbal/766774/Ulica+za+Mancea+u+Zemunu.html.

Runia, E. 'Burying the Dead, Creating the Past', History and Theory 46, no. 3 (2007), 313-325.

Russell, D. 'We All Agree, Name the Stand after Shankly': Cultures of Commemoration in Late TwentiethCentury English Football Culture', Sport in History 26, no. 1 (2006): 1-25.

Savage, K. 'The Politics of Memory: Black Emancipation and the Civil War Monument', in Commemorations: The Politics of National Identity, ed. J. R. Gikllis, Princeton: Princeton University Press, 1994.

Schuman, H. and J. Scott. 'Generations and Collective Memories', American Sociological Review 54 (1989): 35981.

Seifried, C. and K. Meyer. 'Nostalgia-Related Aspects of Professional Sports Facilities: A Facility Audit of Major League Baseball and National Football League Strategies to Evoke the Past', International Journal of Sport Management Recreation and Tourism 5 (2010): 51-76.

Sharpe, G. The Final Whistle: Midfield Fare Wells, Sudden Deaths and Other Strange but True Passings from Football's History. London: Robson, 2001.

Sherman, D. J. The Construction of Memory in Interwar France. Chicago: University of Chicago Press, 1999.

Smith, M. M. 'Frozen Fists in Speed City: The Statue as Twenty-First-Century Reparations', Journal of Sport History 36, no. 3 (2009), 393-414.

Smith, M. M. 'Mapping America's Sporting Landscape: A Case Study of Three Statues', The International Journal of the History of Sport 28, no. 8-9 (2011), 1252-68. 
Speed, I. 'Dragan Mance (Dokumentari Film)' (2008), https://www.youtube.com/watch?v=JcXGJZ4e87U.

Stevens, Q. and K. A. Franck. Memorials as Spaces of Engagement: Design, Use and Meaning. Routledge: London, 2015.

Stride, C. B., F. E. Thomas, and J. P. Wilson. 'The Sporting Statues Project', http://www.sportingstatues.com.

Stride, C. B., F. E. Thomas, J. Wilson and J. Pahigian. 'Modeling Stadium Statue Subject Choice in US Baseball and English Soccer', Journal of Quantitative Analysis in Sports 8, no. 1 (2012): 1-36.

Stride, C. B., J. P. Wilson, and F. E. Thomas. 'From pitch to plinth: documenting the UK's football statuary', Sculpture Journal 22, no. 1 (2013): 146-161.

Stride, C. B., J. P. Wilson, and F. E. Thomas. 'Honouring Heroes by Branding in Bronze', Sport in Society 16, no. 6 (2013): 749-71.

Taylor, M. 'Football History and Memory: The Heroes of Manchester United', Football Studies 3, no. 2 (2000): 24-41.

tribuna.sports.ru, Трибуна Блог, 3 September 2011, http://www.sports.ru/tribuna/blogs/serbian/229955.html.

Unattributed. 'Tuga Sa "Juga"', Večernje Novosti, 5 September 1985

underPFC. 'Tragična Smrt Dragana Mancea (Gusle)'. https://www.youtube.com/watch?v=PulJ-RccwjM.

Walsh, A. J. and R. Giulianotti. 'This Sporting Mammon: a Normative Critique of the Commodification of Sport', Journal of the Philosophy of Sport 28, no. 1, (2001): 53-77.

Wangen, E. Die Gräber Der Götter: Fußballhelden Und Ihre Letzte Ruhestätte. Göttingen: Die Werkstatt, 2009.

Woolridge, J. 'They Shall Not Grow Old': Mourning, Memory and the Munich Air Disaster of 1958', Manchester Region History Review 20 (2009): 111-32. 